S. Galletta, M. Jametti, A. Redonda

Highway to economic growth?

Competition in public works tenders in the Democratic Republic of Congo

Quaderno N. 12-08

Decanato della Facoltà di Scienze economiche

Via G. Buffi, 13 CH-6900 Lugano 


\title{
Highway to Economic Growth? Competition in Public Works Tenders in the Democratic Republic of Congo*
}

\author{
Sergio Galletta ${ }^{\dagger}$ \\ Mario Jametti ${ }^{\ddagger}$ \\ University of Lugano, Switzerland \\ University of Lugano, Switzerland \\ CESifo \\ Agustin Redonda ${ }^{\S}$ \\ University of Lugano, Switzerland
}

November 21, 2012

\begin{abstract}
The Democratic Republic of Congo (DRC) is one of the poorest countries in the World. The construction sector will play an essential part to bring the country on the path of economic growth, and competition within the sector is crucial to achieve this goal. In this paper we analyze the effect of competition in public works tenders in the DRC. Using a unique and newly assembled database on tenders we find that the number of participating bidders and the observed spread of submitted bids both significantly reduce contract prices, confirming our prior that competitive pressure can enhance the overall performance of the sector.
\end{abstract}

Keywords: Construction; competition; tenders; public works.

JEL codes: D44; L13; L74

$<$ Tables and Figures at end $>$

${ }^{*}$ We wish to thank Johannes Herderschee for helpful comments on an earlier draft of the paper. Most of the material was collected as part of a study on the construction sector for the World Bank Country Economic Memorandum for DRC.

${ }^{\dagger}$ Institute of Economics (IdEP), University of Lugano, Via G. Buffi 6, 6904 Lugano, Switzerland; e-mail: sergio.galletta@usi.ch. Also affiliated with the Swiss Public Administration Network (SPAN).

${ }^{\ddagger}$ Corresponding author. Institute of Economics (IdEP), University of Lugano, Via G. Buffi 6, 6904 Lugano, Switzerland; e-mail: mario.jametti@usi.ch. Also affiliated with the Swiss Public Administration Network (SPAN).

${ }^{\S}$ Institute of Economics (IdEP), University of Lugano, Via G. Buffi 6, 6904 Lugano, Switzerland; e-mail: agustin.redonda@usi.ch. Also affiliated with the Swiss Public Administration Network (SPAN). 


\section{Introduction}

The Democratic Republic of Congo (DRC) is one of the largest countries in Sub-Saharan Africa, both by land area and by population. DRC is also the second poorest country of the world as of 2010. After the "lost decade" of war in the 1990's the country is now politically (fairly) stable and on a path to economic recovery. It has tremendous natural resources and an essentially untapped agricultural potential (Herderschee et al., 2011).

The construction sector will play an essential part to bring DRC back on the path of economic growth, via its own contribution to GDP, but more importantly as it may act as the catalyst for growth in other sectors. Basic infrastructure in DRC is in a state of despair. For example, agricultural products can often not be transported to the main urban areas let alone be exported. Similarly, the country presents a vast demand for productive facilities as well as for private housing.

Alas, given the current performance of the sector, it will rather be a bottleneck hindering economic recovery for years to come. Starting 2010, as part of the World Bank's Country Economic Memorandum (CEM) for DRC, a sectorial study of construction services was undertaken (Herderschee et al., 2011). The main findings of this study were: i) the sector is heavily concentrated. Most large infrastructure projects are undertaken by two international (Chinese) firms and only two local companies operate nationwide. Alongside, there exist a multitude of small and medium enterprises, many of them in a precarious financial situation. ii) Most firms lack the proper capabilities to successfully manage a project, which leads to a situation where donor organizations have to provide project management services. iii) There is an important lack of qualified labour, further no official and credible signal for specific human capital exists. Workers are usually hired by some connection to the company or are trained on the spot, without any supporting infrastructure for training. iv) Cement, a major construction input, is also a heavily concentrated sector and prices are among the highest in sub-Saharan Africa.

In this paper we look at one specific aspect of the construction sector in DRC. Does competition in public works tender have a price reducing effect? For this we avail of a newly assembled database on tenders for public construction projects. We measure the competitivity of a tender by two variables: the number of total bidders and the observed spread of submitted bids. Further, we are able to control for unobservables via an array of fixed effects. We find the number of firms submitting a bid significantly reduces the contract's price, while the number of (presumably on technical grounds) qualified firms does not. Similarly, the spread of submitted bids significantly reduces contract price.

The reminder of the paper is as follows. In the next section we briefly present the construction sector in DRC, focusing on market structure. Section 3 reviews the literature on the effects of competition on tender prices and possible ways to measure the degree of competition. In 
section 4 we present the data set and the empirical estimation strategy. In Section 5 we present and discuss the result. Section 6 concludes.

\section{Market Structure in DRC's Construction Sector ${ }^{1}$}

Construction is an important sub-sector within the DRC economy. In 2008 construction and public works represented roughly $8 \%$ of GDP. This accounts for about two thirds of output from the secondary sector. In the beginning of the decade construction and public works were also important contributors to economic growth. Indeed in the period 2000-2006 the growth rate of the sub-sector was considerably above overall GDP growth (see Figure 1). However, growth has slowed down and reached levels comparable to the overall economy in recent years.

It is difficult, i.e. impossible, to obtain reliable information on market participation and market shares for the overall construction sector. The information that is available is taken from a report on road construction (Alliez, 2009). Table 1 presents the most important road construction companies operating in the country, indicating the city of their headquarters, average annual sales and market shares. Since most of these companies operate as general contractors, arguably this table gives a good approximation of market structure in the sector.

Average annual sales of the 15 companies listed in Table 1 are about US\$130 million. It becomes clear from the table that the sector is heavily concentrated. The two most important firms in the country concentrate almost half of sales. The $C_{4}$ concentration ratio is $75 \%$, and, based on the sample, the Hirschman-Herfindahl Index (HHI) is 1615. ${ }^{2}$ However, the information on the local companies leaves out an important actor in the construction sector, i.e. two international firms. Alliez (2009) estimates that over the period 2009-2013 roughly $65 \%$ of road construction will be concentrated among them. Given the important amounts these projects represent we can proceed to a revised estimate of market concentration. We assume that the international firms represent currently about $50 \%$ of the market. Hence the estimated overall $\mathrm{C} 4$ ratio amounts to $(50 \%+48 \% / 2)=74 \%$. If we assume market shares of $30 \%$ and $20 \%$ for the large competitors we obtain a HHI of 1704 . In light of this information, we would argue that it is fair to say that the construction sector in DRC is heavily concentrated, likely giving raise to the negative consequences often observed from lack of competition.

Most of the funding for public infrastructure projects is provided by multi- and bilateral donor agencies, as the government of DRC lacks the proper resources to carry out such projects. Contracts are awarded almost exclusively via first-price tenders, i.e. eligible firms can submit bids for specific contracts and the project is awarded to the lowest bidder. The two main

\footnotetext{
${ }^{1}$ This section draws on the report prepared for the CEM.

${ }^{2}$ Note that the European Commission merger guidelines presume competitive concerns in industries with an HHI above 2000.
} 
agencies carrying out these tenders are the Bureau Central de Coordination (BCECO) and the DRC branch of the United Nations Office for Project Services (UNOPS). BCECO is part of the DRC Ministry of Finance, while, as the name suggests, UNOPS is under the direct supervision of the United Nations.

\section{Literature Background}

The methodological basis of our analysis lies within auction theory. A recent survey of theoretical aspects of auction theory is given in Klemperer (1999). We focus on two aspects that guide the empirics: competition via the number of participants in the tender and issues of asymmetries.

Standard theory implies that more participants increase competition and hence lower price. For example, take the basic Cournot model of oligopolistic competition where the price approaches marginal cost as the number of firms in the market increases. Thus, in a procurement auction context, this competition effect, implies that a higher number of bidders, ceteris paribus, reduces the price paid for the contract. However, increasing the number of participants can also lead to higher equilibrium prices: the winner's curse effect. ${ }^{3}$

Thus, if the winner's curse effect overcomes the gains given by the competition effect, the final output would imply higher contract prices paid by the auctioneer. For example, Bulow and Klemperer (2002) highlight that, in a common-valuation setting, the higher the number of bidders the lower the selling price. ${ }^{4}$ An increase in the number of bidders makes the winner's curse greater, thus competitors should adjust their bids by reducing the actual offer.

The other important aspect in the context of the construction sector in Congo is the presence of asymmetric participants. Traditionally, auction theory has considered that buyers are symmetric ex ante. As mentioned by Maskin and Riley (2000) this can be interpreted as if the preference parameters of the bidders (i.e. their "types") were drawn from a symmetric joint probability distribution. In such a context, all bidders would apply the same equilibrium strategy as a function of their type. In other words, "each potential contractor has essentially the same information about the nature of the project but a different opportunity cost of completing it". ${ }^{5}$ In particular, Maskin and Riley (2000) shows that if a fringe bidder faces a global bidder rather than another weak bidder, she responds with a more aggressive bid distribution in the sense of stochastic dominance. Similarly, if a strong bidder faces a weak bidder rather than

\footnotetext{
${ }^{3}$ The winner's curse in an auction context is a situation where a participant is overly optimistic about the costs to be incurred ending up underestimating them.

${ }^{4}$ In a procurement auction setting this would imply an increase of the contract price given by a higher number of bidders.

${ }^{5}$ Maskin and Riley (2000), p. 414.
} 
another global bidder, she responds with a less aggressive bid distribution. However, as mentioned above, firms in DRC are very heterogeneous. This goes from important variances in size and hence the potential of exploiting economies of scale and scope to many firms lacking proper management experience and financial resources to bring an awarded contract to completion in time and cost. Conceptually, this situation is best modelled via an asymmetric information set among the participants and is usually empirically tackled by controlling for (cost) asymmetries. ${ }^{6}$ Therefore, a higher spread of bids should be an indicator of cost heterogeneity. In a procurement auction context; a higher uncertainty, less information or less managerial experience could lead new entrants to underestimate costs and, therefore, bid too aggressively. In this case, a large spread of bids could not be reflecting the true heterogeneity of bidders' costs but the underestimation of costs by fringe participants. Such a scenario would obviously increase the winner's curse effect. In other words, for the spread of bids to have a positive impact on competition, a sound system of pre-selection must be implemented in order to avoid the winer's curse effect to overcome the competition effect (De Silva et al., 2003).

Procurement auctions have been the focus of vast empirical research in recent years. for example, Gupta (2002) studies the effect of competition in highway construction tenders in Florida. He finds a negative effect of the number of participants on the procurement price. Further, he explores at what number of bidders entrants do not have an effect on the price anymore and finds that a tender becomes competitive with about eight bidders.

Similarly, Estache and Iimi (2010) use data on multi and bilateral development projects and find that a higher number of participants decreases procurement costs and that competitive tenders are achieved with about seven bidders in the road and water sectors. Nevertheless, they find that if, for instance, the number of global bidders is large enough, the auctioneer might have interest in excluding some of the smaller bidders.

De Silva et al. (2003) analyze differences in bidding behavior by incumbent and entrant firms in the road construction set using a dataset of tenders in Oklahoma. The idea behind their analysis is that new entrants may face higher uncertainty, may have access to less information and less managerial experience than incumbent ones. Thus, the dispersion in costs estimates may be larger for them than for incumbent bidders. In addition, the uncertainty given by the presence of entrant firms may affect the bidding conduct of incumbents bidders. They find that the number of participating bidders decreases the price for the contract, hence a price reducing effect of competition. Interestingly, they find that new entrant bidders bid more aggressively and win auctions with significantly lower bids than incumbent ones.

Elmaghraby (2005) questions the commonly held belief that increasing the number of bidders decreases procurement costs and, thus, makes the auction more competitive. His main

\footnotetext{
${ }^{6}$ See for example Elmaghraby (2005).
} 
conclusion states that "more bidders is not always better". ${ }^{7}$ For instance, he states that if the number of global bidders is large enough to encourage competition among them, an auctioneer might want to exclude fringe bidders because global bidders usually bid aggressively in the presence of small ones (particularly when the number of global bidders is small and the fixed set-up cost - that is common to all players and is incurred only once - is large).

Finally, Iimi (2009) looks at infrastructure procurement in sub-Saharan Africa. His focus is on cost overruns and delays, an important problem in public works in Africa and other developing areas, and the effect of ex-post adjustments on bids. He finds that a higher number of participants in the tender increases the price for the procurement contract. Thus, it seems that in his dataset, the winner's curse effect outweighs the competition effect. Further, he instruments the number of bidders as it could be endogenously determined with the submitted bids. He uses the number of qualified firms, i.e. firms that have met all the requirements to participate in the tender, as an instrument. Arguably there are issues with this instrument as the number of participating bidders is a strict subset of the number of qualified firms. In our application, rather than using the number of qualified bidders as an instrument, we use it as an alternative explanatory variable.

Based on these considerations, in order to estimate the effect of competition on tender prices the main determinants are the number of participants in the auction and, potentially, the presence of cost heterogeneities. For both variables the overall effect is theoretically ambiguous, and hence their sign and magnitude remain an empirical matter. To which we now turn.

\section{Data and Estimation}

We have assembled a new database of public works tenders in DRC. Data was assembled from the offices of BECECO and UNOPS. The unit of observation is the lot as some tenders are divided into several lots. We avail of a total of 107 lots. The data is described in more detail in Jametti et al. (2012)

Data assembly and reliability are notoriously difficult in Africa. As such we had to concentrate our efforts considerably. Projects included concentrate on construction of public buildings and road works, in order to increase the comparability among projects. Tenders from the BECECO offices are from the years 2004 to 2006 while the ones from UNOPS are from 2008 to 2010. Geographically eight provinces are represented. Table 2 illustrates the distribution of tenders by province. Further, we distinguish seven types of construction projects. ${ }^{8}$

The information contained in our database includes, besides the type of project and the

\footnotetext{
${ }^{7}$ Elmaghraby (2005), p. 1774.

${ }^{8}$ These are: public building (52 projects), schools (28), road work (5), hospitals and others (6), housing (10), markets (3), water (3).
} 
province: the (negotiated) contract price, the number of participating bidders, the number of qualified bidders and the bid submitted by each qualified participant. ${ }^{9}$ We used this information to construct the following variables which we use in the empirical analysis.

Contract price is the final negotiated price of the tendering lot. Note that in principle this corresponds to the lowest bid, as all tenders are first price tenders conditional on being qualified on technical grounds. However, firms often renegotiate contracts after having won them. Indeed in our sample, the contract price is higher than the lowest bid (=winning company) in 37\% of the observations (39 out of 107). As dependent variable, in order to make projects more comparable across observations, we constructed a relative price variable, contract percentage, which is defined as the ratio between the contract price and the mean of submitted bids. The number of bidders is the total count of companies that participated in the tender. Further, qualified bidders is the number of firms that are retained as being qualified to participate. In principle firms should be disqualified only on technical grounds. Finally, we define spread of bids as the difference between the second lowest and the highest bid as a percentage of the contract price. We choose the second lowest bid for spread in order to avoid mechanical reverse causality problems. Table 3 presents summary statistics of our variables. The average contract price is about MUS $\$ 1$, ranging from slightly less than US $\$ 3500$ to MUS\$15.5. Interestingly, the contracting price is sometimes higher than the mean of bids, which is illustrated by the unexpected maximum of contract percentage larger than one. Indeed, inspection of the data showed that there are five (5) observations like this. The average number of bidders was about 10, ranging from 3 to 35 participants. However, only about half the participants (5) were qualified and entered the competition. Note that in two observations only one bidder survived. Finally, there is important variation in the spread of bids, ranging from 0 (for observations where only one bidder survived) to more than 16 . This latter values implies that the maximum bid is up to 16 times higher than the lastly negotiated contract.

Our regression equation is

$$
\text { contract percentage }_{i}=\alpha+\beta_{1} \text { bidder }_{i}+\beta_{2} \text { spread }_{i}+F E+u_{i},
$$

where bidders is, alternatively, the number of total bidders and the number of qualified ones and $F E$ are a number of fixed effects. Indeed within our database we cannot control for other variables that might explain differences in contract prices. Instead, we are able to control unobserved variation via the inclusion of fixed effects. In all our equations we include type effects to control for cost differences across projects of various nature. In our preferred specification we also include time and province effects. Arguably, we are thus able to control

\footnotetext{
${ }^{9}$ Unfortunately we were unable to assemble any information on the extent of works to be carried out. Thus, we cannot perform any unit cost analysis (e.g. cost per kilometer of road).
} 
for most of the relevant unobservables.

We estimate the above equation using OLS with clustering at the level of project types. Further we estimate the regressions using the log of bidders to allow for a diminishing competitive effect with a large number of bidders.

\section{Results and Discussion}

Table 4 presents our results. Columns (1) and (4) are our base specifications, the latter using $\log$ (bidders). In these regressions only project type effects are included. We observe a negative and statistically significant (at the 10\%-level) effect of the number of bidders on the contract price. This suggests that competition in the bidding project indeed works by lowering negotiated final prices. We also find a negative and statistically highly significant effect of the spread of bids on the final price.

Columns (2) and (5) present our preferred results including, besides the project type effects, also time and province effects. The base results are confirmed and actually slightly stronger. We are able to estimate precisely a negative competition effect, slightly smaller in magnitude than in the base regression. Similarly, the effect of spread remains unchanged, indicating that lager variation in the submitted bids actually lowers the finally negotiated price.

Finally, columns (3) and (6) present a robustness check, where we include the number of qualified bidders instead of the total number of participants. Note that this variable is not significant in our specifications. Thus, what seems to matter in our dataset is the overall participation rate. The number of qualified firms based on technical grounds does not seem to be the adequate measure for competition.

Although these results are significant and robust, their magnitude is rather small. Looking at the competition effect using our preferred regression (column (2)), we can infer that a one standard deviation increase in the number of bidders would increase the contract percentage by roughly $2.4 \%$. Evaluating this at the mean of contracts, this implies that increasing the number of participants by seven (7) would lead to average reductions of about $\$ 20$ '000 per project. Similarly, an increase of one standard deviation on the spread of bids (implying that the largest bid would almost double) reduces the contract percentage by approximately $8 \%$.

\section{Conclusion}

The construction sector will play a crucial role in future economic growth of the Democratic Republic of Congo (DRC). Both public and private sector demand for construction in the country is immense. One base for economic relaunch will be a well functioning construction 
sector. In this paper we empirically investigate the effect of competition on public works tenders in a newly assembled database for projects in most areas of DRC between 2004 and 2010.

We measure competitive pressure by the number of bidders participating in each project as well as the observed spread of submitted bids. Further, we are able to control for unobserved variation using a number of fixed effects.

We find that the number of participating bidders, rather than the number of qualified ones, affects significantly and negatively the obtained contract price. Thus, competition works and has a price reducing effect, although rather small in magnitude. Interestingly, the spread of bids also has a negative effect on prices. Hence, participation of fringe bidders, although with potentially higher costs, appears to increase the competitive effect of tenders.

Based on these results, public tender organizers, in our case BECECO and UNOPS, should incentivize the participation of a larger number of bidders for each project. These fringe bidders exerce competitive pressure on the incumbents, even if they might be disqualified on technical grounds and present potentially higher costs. 


\section{References}

Alliez, Jean-Luc (2009) 'Diagnostic préliminaire pour le développement de l'industrie de la construction routière.' Rapport Cellule Infrastructures, Kinshasa

Bulow, Jeremy, and Paul Klemperer (2002) 'Prices and the winner's curse.' RAND Journal of Economics 33(1), 1-21

De Silva, Dakshina G., Timothy Dunne, and Georgia Kosmopoulou (2003) 'An empirical analysis of entrant and incumbent bidding in road construction auctions.' Journal of Industrial Economics 51(3), 295-316

Elmaghraby, Wedad (2005) 'The effect of asymmetric bidder size on an auction's performance: Are more bidders always better?' Management Science 51(12), 1763-1776

Estache, Antonio, and Atsushi Iimi (2010) 'Bidder asymmetry in infrastructure procurement: Are there any fringe bidders?' Review of Industrial Organization 36(2), 163-187

Gupta, Srabana (2002) 'Competition and collusion in a government procurement auction market.' Atlantic Economic Journal 30(1), 13-25

Herderschee, J., K.A. Kaiser, and D.M. Samba (2011) Resilience of an African Giant: Boosting Growth and Development in the Democratic Republic of Congo (World Bank Publications, Washington)

Iimi, Atsushi (2009) 'Infrastructure procurement and ex post cost adjustment evidence from oda-financed road procurement in africa.' mimeo

Jametti, Mario, Paul Tshiula Tshimanga, and Salim Malouf (2012) 'La construction: un goulot d'étranglement économique pour l'avenir.' In Résilience d'un Géant Africain, ed. J. Herderschee, M.T. Tshibangu, and D.M. Samba, vol. 2 (MEDIASPAUL, Kinshasa DRC)

Klemperer, Paul (1999) 'Auction theory: A guide to the literature.' Journal of Economic Surveys $13(3), 227-86$

Maskin, Eric, and John Riley (2000) 'Asymmetric auctions.' Review of Economic Studies $67(3), 413-38$ 
Table 1: Market Shares of Main Local Construction Companies

\begin{tabular}{|c|c|c|c|}
\hline Company Name & City & Avg Sales (2003 - 2008) M US & Market Shares \\
\hline EGMF (Enterprise Generale Malta Forrest) & Lubumbashi & 32.0 & $24.90 \%$ \\
\hline Safricas & Kinshasa & 30.0 & $23.35 \%$ \\
\hline MW Afritec & Kinshasa & 20.0 & $15.56 \%$ \\
\hline Number One Contractors & Kinshasa & 14.0 & $10.89 \%$ \\
\hline Bego Congo & Kinshasa - Kisangani & 8.0 & $6.23 \%$ \\
\hline Sefoco & Ingende & 6.0 & $4.67 \%$ \\
\hline AVC Construct & Kinshasa & 3.0 & $2.33 \%$ \\
\hline Const Soco (Groupe Ledya) & Kinshasa & 3.0 & $2.33 \%$ \\
\hline Enterprise Fretin & Matadi & 3.0 & $2.33 \%$ \\
\hline Safrimex & Kinshasa & 3.0 & $2.33 \%$ \\
\hline FS Parisi & Kinshasa & 2.0 & $1.56 \%$ \\
\hline INCC & Lusambo & 2.0 & $1.56 \%$ \\
\hline BACOM & Kinshasa & 1.5 & $1.17 \%$ \\
\hline ADI Construct & Kinshasa & 0.5 & $0.39 \%$ \\
\hline Batech & Kinshasa & 0.5 & $0.39 \%$ \\
\hline
\end{tabular}

(Alliez, 2009)

Table 2: Distribution of Tenders by Province and Source

\begin{tabular}{lccc}
\hline Province & BECECO & UNOPS & Total \\
\hline Bandundu & 0 & 9 & 9 \\
Bas Congo & 0 & 6 & 6 \\
Equateur & 0 & 3 & 3 \\
Katanga & 0 & 4 & 4 \\
Kinshasa & 30 & 9 & 39 \\
Nord-Kivu & 0 & 11 & 11 \\
Orientale & 0 & 9 & 9 \\
Sud-Kivu & 0 & 26 & 26 \\
\hline
\end{tabular}


Table 3: Summary statistics

\begin{tabular}{lccccc}
\hline \multicolumn{1}{c}{ Variable } & Mean & Std. Dev. & Min. & Max. & N \\
\hline Contract Price & 987.98 & 3234.46 & 3.435 & 15493.24 & 107 \\
Total Bidders & 10.13 & 7.2 & 3 & 35 & 97 \\
Qualified Bidders & 4.95 & 2.94 & 1 & 18 & 100 \\
Spread & 0.91 & 1.70 & 0 & 16.17 & 104 \\
\hline
\end{tabular}

Table 4: Results

\begin{tabular}{lcccccc}
\hline & $(1)$ & $(2)$ & $(3)$ & $(4)$ & $(5)$ & $(6)$ \\
\hline Tot Bidders & $-0.004^{*}$ & $-0.003^{* * *}$ & & & & \\
& $(0.002)$ & $(0.001)$ & & & & \\
Spread & $-0.037^{* * *}$ & $-0.036^{* * *}$ & $-0.043^{* *}$ & $-0.037^{* * *}$ & $-0.036^{* * *}$ & $-0.044^{* *}$ \\
& $(0.002)$ & $(0.008)$ & $(0.015)$ & $(0.002)$ & $(0.009)$ & $(0.017)$ \\
Qualified Bidders & & & -0.000 & & & \\
& & & $(0.004)$ & & & \\
l(Tot Bidders) & & & & $-0.043^{*}$ & $-0.022^{* *}$ & \\
& & & & $(0.018)$ & $(0.006)$ & \\
l(Qualified Bidders) & & & & & & 0.008 \\
& & & & & & $0.035)$ \\
Constant & $0.851^{* * *}$ & $0.866^{* * *}$ & $0.819^{* * *}$ & $0.897^{* * *}$ & $0.884^{* * *}$ & $0.803^{* *}$ \\
& $(0.018)$ & $(0.138)$ & $(0.184)$ & $(0.037)$ & $(0.140)$ & $(0.219)$ \\
\hline $\mathrm{R}^{2}$ & 0.302 & 0.403 & 0.436 & 0.296 & 0.399 & 0.436 \\
$\mathrm{~N}$ & 94 & 89 & 92 & 94 & 89 & 92 \\
\hline
\end{tabular}




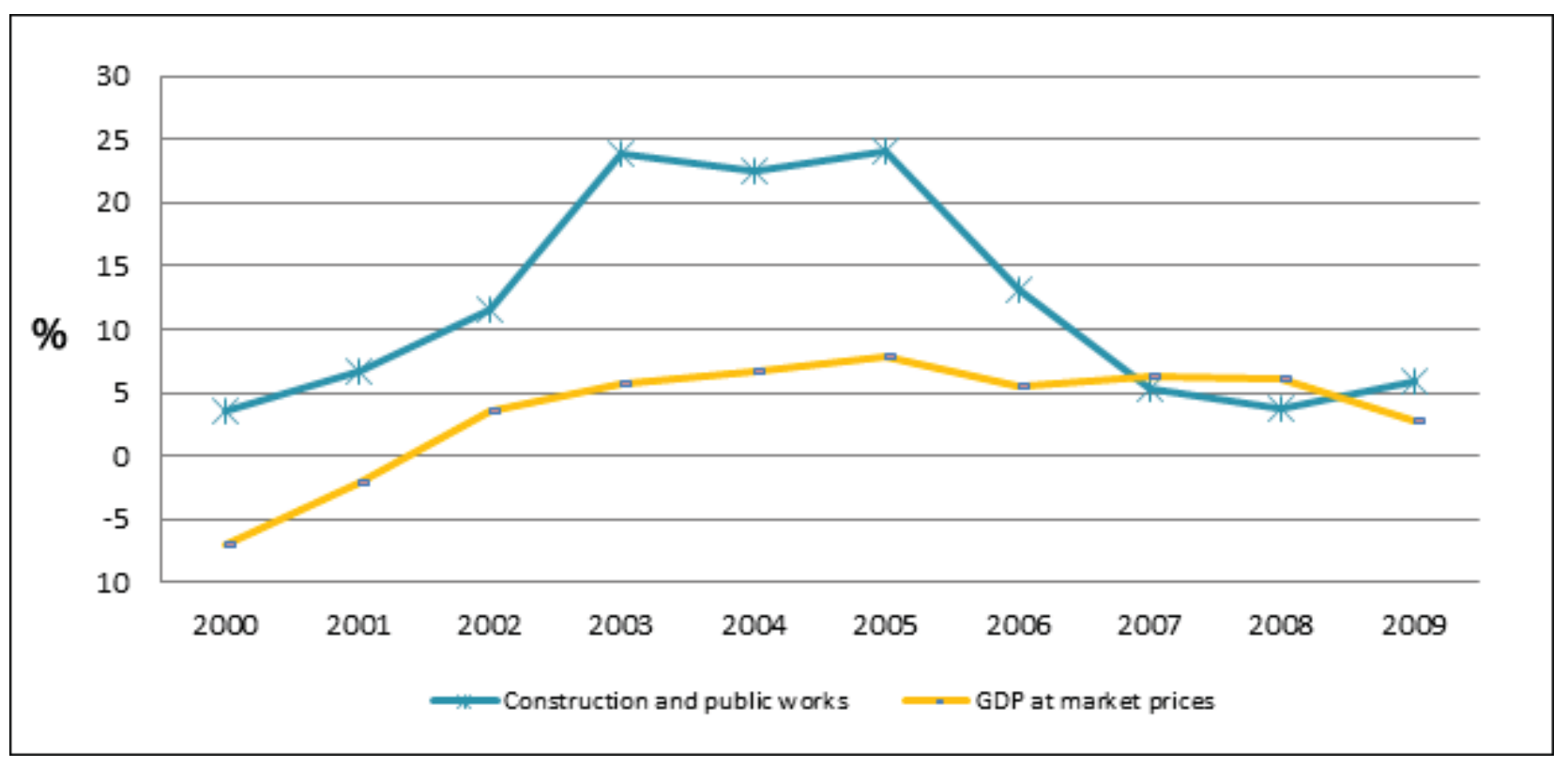

Figure 1: Sectoral and Overall GDP growth. 


\section{QUADERNI DELLA FACOLTÀ}

1998:

P. Balestra, Efficient (and parsimonious) estimation of structural dynamic error component models

1999:

M. Filippini, Cost and scale efficiency in the nursing home sector : evidence from Switzerland

L. Bernardi, I sistemi tributari di oggi : da dove vengono e dove vanno

L.L. Pasinetti, Economic theory and technical progress

G. Barone-Adesi, K. Giannopoulos, L. Vosper, VaR without correlations for portfolios of derivative securities

G. Barone-Adesi, Y. Kim, Incomplete information and the closed-end fund discount

G. Barone-Adesi, W. Allegretto, E. Dinenis, G. Sorwar, Valuation of derivatives based on CKLS interest rate models

M. Filippini, R. Maggi, J. Mägerle, Skalenerträge und optimale Betriebsgrösse bei den schweizerische Privatbahnen

E. Ronchetti, F. Trojani, Robust inference with GMM estimators

G.P. Torricelli, I cambiamenti strutturali dello sviluppo urbano e regionale in Svizzera e

nel Ticino sulla base dei dati dei censimenti federali delle aziende 1985, 1991 e 1995

2000:

E. Barone, G. Barone-Adesi, R. Masera, Requisiti patrimoniali, adeguatezza del capitale e gestione del rischio

G. Barone-Adesi, Does volatility pay?

G. Barone-Adesi, Y. Kim, Incomplete information and the closed-end fund discount $\mathrm{R}$. Ineichen, Dadi, astragali e gli inizi del calcolo delle probabilità

W. Allegretto, G. Barone-Adesi, E. Dinenis, Y. Lin, G. Sorwar, A new approach to check the free boundary of single factor interest rate put option

G.D.Marangoni, The Leontief Model and Economic Theory

B. Antonioli, R, Fazioli, M. Filippini, I/ servizio di igiene urbana italiano tra concorrenza e monopolio

L. Crivelli, M. Filippini, D. Lunati. Dimensione ottima degli ospedali in uno Stato federale

L. Buchli, M. Filippini, Estimating the benefits of low flow alleviation in rivers: the case of the Ticino River

L. Bernardi, Fiscalità pubblica centralizzata e federale: aspetti generali e il caso italiano attuale

M. Alderighi, R. Maggi, Adoption and use of new information technology

F. Rossera, The use of log-linear models in transport economics: the problem of commuters' choice of mode

2001:

M. Filippini, P. Prioni, The influence of ownership on the cost of bus service provision in

Switzerland. An empirical illustration

B. Antonioli, M. Filippini, Optimal size in the waste collection sector

B. Schmitt, La double charge du service de la dette extérieure

L. Crivelli, M. Filippini, D. Lunati, Regulation, ownership and efficiency in the Swiss

nursing home industry

S. Banfi, L. Buchli, M. Filippini, Il valore ricreativo del fiume Ticino per i pescatori

L. Crivelli, M. Filippini, D. Lunati, Effizienz der Pflegeheime in der Schweiz 
2002:

B. Antonioli, M. Filippini, The use of a variable cost function in the regulation of the Italian water industry

B. Antonioli, S. Banfi, M. Filippini, La deregolamentazione del mercato elettrico svizzero e implicazioni a breve termine per l'industria idroelettrica

M. Filippini, J. Wild, M. Kuenzle, Using stochastic frontier analysis for the access price regulation of electricity networks

$\mathrm{G}$. Cassese, On the structure of finitely additive martingales

2003:

M. Filippini, M. Kuenzle, Analisi dell'efficienza di costo delle compagnie di bus italiane e svizzere

C. Cambini, M. Filippini, Competitive tendering and optimal size in the regional bus transportation industry

L. Crivelli, M. Filippini, Federalismo e sistema sanitario svizzero

L. Crivelli, M. Filippini, I. Mosca, Federalismo e spesa sanitaria regionale : analisi empirica per i Cantoni svizzeri

M. Farsi, M. Filippini, Regulation and measuring cost efficiency with panel data models : application to electricity distribution utilities

M. Farsi, M. Filippini, An empirical analysis of cost efficiency in non-profit and public nursing homes

F. Rossera, La distribuzione dei redditi e la loro imposizione fiscale : analisi dei dati fiscali svizzeri

L. Crivelli, G. Domenighetti, M. Filippini, Federalism versus social citizenship :

investigating the preference for equity in health care

M. Farsi, Changes in hospital quality after conversion in ownership status

G. Cozzi, O. Tarola, Mergers, innovations, and inequality

M. Farsi, M. Filippini, M. Kuenzle, Unobserved heterogeneity in stochastic cost frontier models : a comparative analysis

2004:

G. Cassese, An extension of conditional expectation to finitely additive measures

$\mathrm{S}$. Demichelis, O. Tarola, The plant size problem and monopoly pricing

F. Rossera, Struttura dei salari 2000 : valutazioni in base all'inchiesta dell'Ufficio federale di statistica in Ticino

M. Filippini, M. Zola, Economies of scale and cost efficiency in the postal services :

empirical evidence from Switzerland

F. Degeorge, F. Derrien, K.L. Womack, Quid pro quo in IPOs : why book-building is dominating auctions

M. Farsi, M. Filippini, W. Greene, Efficiency measurement in network industries : application to the Swiss railway companies

L. Crivelli, M. Filippini, I. Mosca, Federalism and regional health care expenditures : an empirical analysis for the Swiss cantons

S. Alberton, O. Gonzalez, Monitoring a trans-border labour market in view of liberalization : the case of Ticino

M. Filippini, G. Masiero, K. Moschetti, Regional differences in outpatient antibiotic consumption in Switzerland

A.S. Bergantino, S. Bolis, An adaptive conjoint analysis of freight service alternatives : evaluating the maritime option

2005:

M. Farsi, M. Filippini, An analysis of efficiency and productivity in Swiss hospitals M. Filippini, G. Masiero, K. Moschetti, Socioeconomic determinants of regional differences in outpatient antibiotic consumption : evidence from Switzerland 
2006:

M. Farsi, L. Gitto, A statistical analysis of pain relief surgical operations

M. Farsi, G. Ridder, Estimating the out-of-hospital mortality rate using patient discharge data

S. Banfi, M. Farsi, M. Filippini, An empirical analysis of child care demand in Switzerland

L. Crivelli, M. Filippini, Regional public health care spending in Switzerland : an empirical analysis

M. Filippini, B. Lepori, Cost structure, economies of capacity utilization and scope in Swiss higher education institutions

M. Farsi, M. Filippini, Effects of ownership, subsidization and teaching activities on hospital costs in Switzerland

M. Filippini, G. Masiero, K. Moschetti, Small area variations and welfare loss in the use of antibiotics in the community

A. Tchipev, Intermediate products, specialization and the dynamics of wage inequality in the US

A. Tchipev, Technological change and outsourcing : competing or complementary explanations for the rising demand for skills during the 1980s?

2007:

M. Filippini, G. Masiero, K. Moschetti, Characteristics of demand for antibiotics in primary care : an almost ideal demand system approach

G. Masiero, M. Filippini, M. Ferech, H. Goossens, Determinants of outpatient antibiotic consumption in Europe : bacterial resistance and drug prescribers

R. Levaggi, F. Menoncin, Fiscal federalism, patient mobility and the soft budget constraint : a theoretical approach

M. Farsi, The temporal variation of cost-efficiency in Switzerland's hospitals : an application of mixed models

2008:

M. Farsi, M. Filippini, D. Lunati, Economies of scale and efficiency measurement in Switzerland's nursing homes

A. Vaona, Inflation persistence, structural breaks and omitted variables : a critical view

A. Vaona, The sensitivity of non parametric misspecification tests to disturbance autocorrelation

A. Vaona, STATA tip : a quick trick to perform a Roy-Zellner test for poolability in STATA

A. Vaona, R. Patuelli, New empirical evidence on local financial development and growth

C. Grimpe, R. Patuelli, Knowledge production in nanomaterials : an application of spatial filtering to regional system of innovation

A. Vaona, G. Ascari, Regional inflation persistence : evidence from Italy

M. Filippini, G. Masiero, K. Moschetti, Dispensing practices and antibiotic use

T. Crossley, M. Jametti, Pension benefit insurance and pension plan portfolio choice

R. Patuelli, A. Vaona, C. Grimpe, Poolability and aggregation problems of regional

innovation data : an application to nanomaterial patenting

J.H.L. Oud, H. Folmer, R. Patuelli, P. Nijkamp, A spatial-dependence continuous-time

model for regional unemployment in Germany

2009:

J.G. Brida, S. Lionetti, W.A. Risso, Long run economic growth and tourism : inferring from Uruguay

R. Patuelli, D.A. Griffith, M. Tiefelsdorf, P. Nijkamp, Spatial filtering and eigenvector stability : space-time models for German unemployment data

R. Patuelli, A. Reggiani, P. Nijkamp, N. Schanne, Neural networks for cross-sectional employment forecasts : a comparison of model specifications for Germany

A. Cullmann, M. Farsi, M. Filippini, Unobserved heterogeneity and International

benchmarking in public transport

M. Jametti, T. von Ungern-Sternberg, Hurricane insurance in Florida

S. Banfi, M. Filippini, Resource rent taxation and benchmarking : a new perspective for the Swiss hydropower sector 
S. Lionetti, R. Patuelli, Trading cultural goods in the era of digital piracy

M. Filippini, G. Masiero, K. Moschetti, Physician dispensing and antibiotic prescriptions

2010:

R. Patuelli, N. Schanne, D.A. Griffith, P. Nijkamp, Persistent disparities in regional unemployment : application of a spatial filtering approach to local labour markets in Germany

K. Deb, M. Filippini, Public bus transport demand elasticities in India

L. Masiero, R. Maggi, Estimation of indirect cost and evaluation of protective measures for infrastructure vulnerability : a case study on the transalpine transport corridor

L. Masiero, D.A. Hensher, Analyzing loss aversion and diminishing sensitivity in a freight transport stated choice experiment

L. Masiero, D.A. Hensher, Shift of reference point and implications on behavioral reaction to gains and losses

J.M. Rose, L. Masiero, A comparison of prospect theory in WTP and preference space

M. Filippini, M. Koller, U. Trinkner, Do opening hours and unobserved heterogeneity affect economies of scale and scope in postal outlets?

G. Guerra, R. Patuelli, R. Maggi, Ethnic concentration, cultural identity and immigrant self-employment in Switzerland

S. Lionetti, Tourism productivity : incentives and obstacles to fostering growth

G. Guerra, R. Patuelli, The influence of role models on immigrant self-employment : a spatial analysis for Switzerland

M. Filippini, L. Gonzalez, G. Masiero, Estimating dynamic consumption of antibiotics using panel data : the shadow effect of bacterial resistance

2011:

Quaderno n. 11-01

L. Masiero, J.L. Nicolau, Price sensitivity to tourism activities : looking for determinant factors

Quaderno n. 11-02

L. Masiero, J.L. Nicolau, Finding similar price preferences on tourism activities

Quaderno n. 11-03

L. Masiero, R. Maggi, Accounting for WTP/WTA discrepancy in discrete choice models :

discussion of policy implications based on two freight transport stated choice experiments

Quaderno n. 11-04

L. Masiero, J.M. Rose, The role of the reference alternative in the specification of asymmetric discrete choice models

Quaderno n. 11-05

D. Engel, T. Mitze, R. Patuelli, J. Reinkowski, Does the support of innovative clusters sustainably foster R\&D activity? Evidence from the German BioRegio and BioProfile contests

Quaderno n. 11-06

L. González, G. Masiero, Disentangling spillover effects of antibiotic consumption : a spatial panel approach

Quaderno n. 11-07

M. Jametti, M. Joanis, Electoral competition as a determinant of fiscal decentralization 
2012:

Quaderno n. 12-01

G. Guerra, The role of job satisfaction in transitions into self-employment

Quaderno n. 12-02

M. Filippini, L.G. González Ortiz, G. Masiero, Assessing the impact of antibiotic policies in Europe

Quaderno n. 12-03

L. Di Giorgio, M. Filippini, G. Masiero, The impact of the institutional form on the cost efficiency of nursing homes

Quaderno n. 12-04

M. Filippini, G. Masiero, D. Medici, The demand for school meals : an analysis of stated choices by Swiss househols

Quaderno n. 12-05

L. Masiero, J. Zoltan, Tourists intra-destination visits and transportation mode : a bivariate model

Quaderno n. 12-06

M. Filippini, M. Koller, Cost efficiency measurement in postal delivery networks

Quaderno n. 12-07

S. Galletta, M. Jametti, How to tame two leviathans? Revisiting the effect of direct democracy on local public expenditure

Quaderno n. 12-08

S. Galletta, M. Jametti, A. Redonda, Highway to economic growth? Competition in public works tenders in the Democratic Republic of Congo 